\title{
Developmental Dysplasia of the Hip
}

\author{
Autores: J. Richard Bowen e ANAStAcio KotZIAS-Neto \\ Publicado por Data Trace Publishing Company P.O. Box \\ 1239, Brooklandville, Maryland 21022-9978-USA
}

Publicado em 2006 e escrito em inglês, o livro aborda apenas um tópico dentro do vasto campo da ortopedia: a Displasia de Desenvolvimento do Quadril. Experientes ortopedistas pediátricos, os doutores Bowen e Kotzias conseguiram elaborar um texto que abrange os vários aspectos desta condição de forma clara, didática e atual.

O livro foi publicado no tipo brochura e dele constam 324 páginas, contendo inúmeras ilustrações, figuras, fotografias e radiografias, sempre com explicações anexas, permitindo fácil entendimento.

As referências obedecem, rigorosamente, as citações do texto, sendo muito úteis, especialmente para os que pretendem obter maiores informações sobre assuntos específicos.

Ao longo dos doze capítulos encontram-se as descrições de toda a evolução da enfermidade, sua história natural, tipos de tratamento e complicações.

Penso que a leitura desta obra é aconselhável para os residentes de ortopedia, os ortopedistas generalistas e também para os ortopedistas pediátricos.

Paulo Cezar de Malta Schott

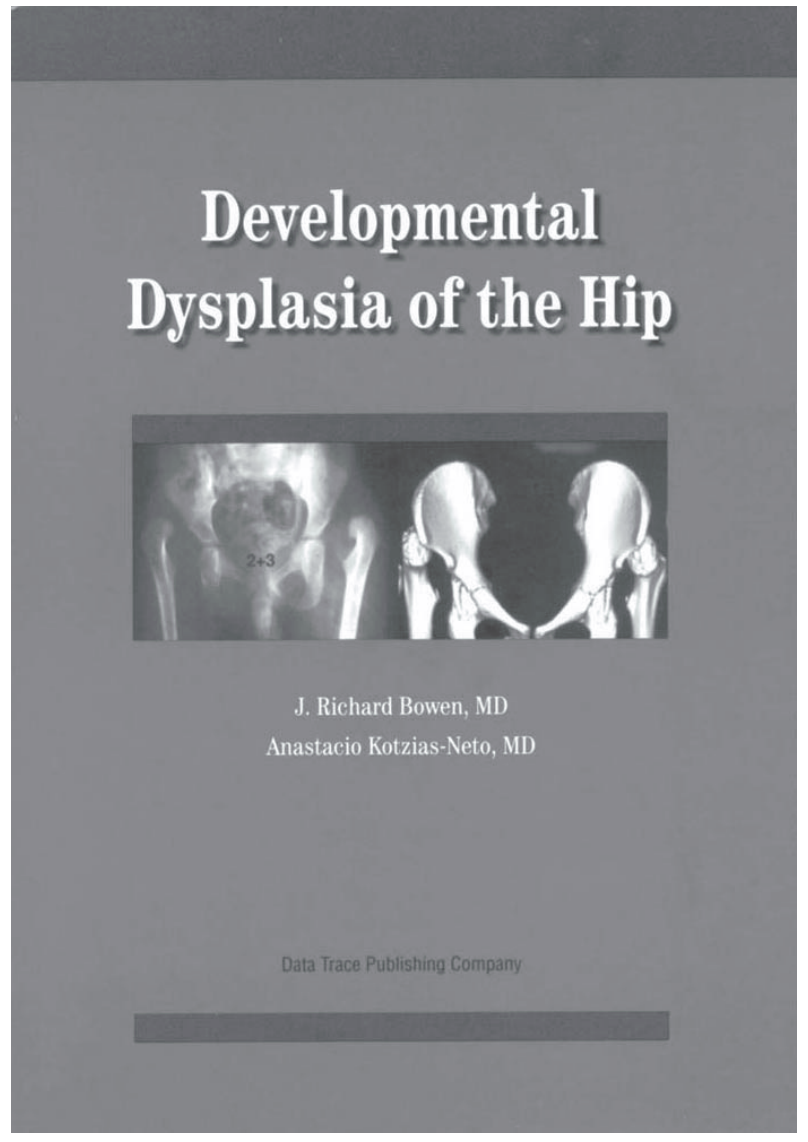

